\title{
Dynamic Modeling of Energy Consumption Pattern of a Typical Nigerian Average Urban and Rural Household for Microgrid PV Design
}

\author{
Ye-Obong Udoakah, Emmanuel Mudaheranwa and Liana Cipcigan \\ Center for Integrated Renewable Energy Generation and Supply \\ School of Engineering \\ Cardiff University \\ Cardiff, Uk \\ Udoakahyn1@cardiff.ac.uk, Mudaheranwae@cardiff.ac.uk, Cipciganlm@cardiff.ac.uk
}

\begin{abstract}
The knowledge of consumer electricity consumption is essential for the design of smart grid integration strategies and distributed generation. In recent times, the total energy consumption in the residential sector has continued to increase resulting from economic expansions, population and floor area growth which is an indication of a consistently increasing demand. Energy independence as part of the solution to energy efficiency has become a pressing issue for today's society. Using AutoCAD software alongside with an Excel spreadsheet, the average-demand, load factor, demand-factor and unit power density of the designed building were computed for an average urban and rural household. The hourly load profile of the building and percentage energy usage across both locations for the various seasons were determined. Lastly, a comparative performance of LED and Incandescent Lighting schemes were examined. It is hoped that the results of this study would help the decisions of the residential energy users.
\end{abstract}

Index Terms-Electricity Consumption, Energy Efficiency, Lighting Schemes, Load Profile, Smart grid

\section{INTRODUCTION}

The central role of energy in the accomplishments of most of the sustainable developments goals can never be overemphasized. Specifically, residential energy which represents about $35 \%$ of global energy use according to [1], [2] plays an important role in the achievement of sustainable development and providing affordable and clean energy remains one of the most challenging tasks for governments and policy makers around the world today.

The sustainability of any smart microgrid design is anchored on energy efficiency consideration. Hence, the first step in the design of any smart PV microgrid system is carrying out a critical load evaluation [3]. Achieving the highest level of energy efficiency by the implementation of various control strategies alongside Demand Response (DR) schemes has continued to dominate the front burner of most energy researches.
The emergence of smart grids with enhanced data communication capabilities which hitherto was not part of the traditional grid, has propelled DR to be an essential part of the next generation power distribution system. This without doubts has introduced many challenges in the distribution network as most traditional grids were not designed to accommodate distributed energy resources. However, such upgrade will culminate into new capabilities that will increase the efficiency, reliability, interoperability, and security of the electric system.

The international Energy Agency (IEA) energy efficiency 2018 report [4] indicates that globally, after about two years of low growth, the energy demand grew by $2 \%$ in 2017 , while the global energy intensity dropped by $1.7 \%$ which was observed to be the smallest annual improvement in ten years. On the whole, the progress was attributed to the ongoing global energy efficiency campaign. For instance, the report noted that since 2000, resulting from improvements in energy efficiency in the world's major economies, more than onethird of the increase in energy-using activities had been reduced. Clearly, the milestone so far achieved is indicative of the fact that energy efficiency is capable of delivering economic, environmental and social benefits if effective energy efficient measures are holistically implemented across all sectors.

The highlights from the report observed two important trends. Firstly, the energy use in the buildings sector continued to grow as expected, resulting from economic expansions, population and floor area growth. Secondly, remarkable energy savings was achieved resulting from effective energy efficient buildings and appliances. On the contrary, the report observed that energy use in the building sector would have been $12 \%$ higher in 2017 if considerations were not given to energy efficiency improvements. From the statistics, it was seen that between 2000 and 2017, the final energy use in buildings and appliances increased by $21 \%$ to 
reach 120 exajoule (EJ), resulting in an energy savings of 14 EJ [4].

The global energy efficiency improvements outlook appears to be significant, unfortunately, this outlook may not be so impressive when country specific scenarios are considered. For instance a recent electricity consumers' energy efficiency awareness evaluation research carried out in some parts of Nigeria indicated that the use of incandescent lamps in residential buildings were still very prevalent even among households with high literacy level. The research further revealed that even when customers asserted to the knowledge of energy efficient devices and its advantages, a sizeable percentage still did not subscribe to using them [5].

In view of the important milestone so far achieved in energy savings at the global scale resulting from the use of energy efficient technology and the need to replicate same at the local levels that this research is carried out. The objective of this study is to model the energy use pattern for a typical urban and rural household in Nigeria taking into consideration the seasonal variations. The study also aims to determine the building unit power density and perform an economic analysis of the different lighting schemes for optimum energy efficiency. Specifically, the results of the model would be used for future smart PV localized sustainable microgrid energy system designs which would enhance energy efficiency and sustainability.

\section{LITERATURE REVIEW}

With respect to Nigeria, several studies have been carried out with regards to energy consumption pattern. For instance, using a stratified three-stage random sampling technique, an assessment of the domestic load demand of rural areas in southwestern Nigeria was performed by [6]. The four villages were randomly selected and the result shows that for basic power requirements, households in Nigeria would require $2324.5 \mathrm{Wh} / \mathrm{h}$ or $850.8 \mathrm{kWh} / \mathrm{yr}$ to meet their power demand. Similarly, [7] investigated the energy utilization pattern of Nigeria for possible areas of conservation in the major economic sectors. The outcome of the study revealed six major areas through which conservation measures could enhance energy savings. The residential building noted for the dominant use of incandescent bulb which is energy intensive was listed as one of sectors where energy conservation could be achieved. The study concluded that there was potential for significant energy savings if Nigerians replaced their incandescent bulbs with energy efficient bulbs. The energy consumption end use of some selected residential buildings in Northern Nigeria was conducted by [8]. The study assessed the energy usage and intensity of buildings asbuilt and when retrofitted with green features. Resulting from the analysis of variance carried out at $0.05 \%$, it was observed that there was a significant difference in the energy consumption of both buildings. Based on the results, the annual energy intensity of both buildings were determined and compared with that of the green features showing significant energy savings. In order to meet the basic energy demand of an average household using a solar PV system, [9] proposed the use partitioning approach based on the scalable level of importance to quality of life. Using a typical medium income house as a case study, different analysis was performed based on the level of quality of life that can be afforded by different users. The result revealed that the life cycle cost over a period of 20 years, of solar energy system for level 1 (Lighting only) which has the highest impact on the quality of life of Nigerian is $\$ 10,600$.

\section{DESIGN MODEL}

According to [10], the modeling and analysis of a power system depends upon the load which is always changing. In order to understand the changing load pattern, an evaluation of an individual customer load is inevitable. Determining the load of any customer cannot be done in space, therefore a building design or layout is required. Using AutoCAD design software, the model of a typical average residential building in Nigeria was developed as shown in Figure 1. Loads are estimated either through measurements in real time using energy monitoring system or estimated based on expected load ratings resulting from the user's knowledge of daily building activities. Using an Excel Spreadsheet, the various electric energy consumed by the loads from each room in the building design layout and the duration of usage were estimated. Based on the estimates, the daily kilowatt-hours $(\mathrm{kWh})$ consumption for both the urban and rural residence for the dry and rainy seasons respectively was estimated. Also, using the hourly load curve developed from the model, the maximum demand and the time of occurrence was determined for both locations and seasons. The average demand, load factor, demand factor and unit power density of building were computed using equations 1 to 4 . The percentage of energy use of each appliance was determined and the techno-economic analysis of the two lighting schemes (Incandescent bulbs and Light Emitting Diodes (LED) bulbs) was performed. The total area of the building from the designed layout is $1,308.13 \mathrm{ft}^{2}$.

\begin{tabular}{|c|c|c|}
\hline Average Demand $=$ & $\frac{\text { Total Energy }}{\text { Hours }}$ & 1 \\
\hline Load Factor $=$ & $\frac{\text { Average Hourly Demand }}{\text { Maximum Hourly Demand }}$ & 2 \\
\hline Demand Factor $=$ & $\frac{\text { Maximum Demand }}{\text { Total Connected Load }}$ & 3 \\
\hline Unit Power Density = & $\frac{\text { Average Power Requirement }}{\text { Square Footage of Building }}$ & 4 \\
\hline \multicolumn{3}{|c|}{ Energy Consume $=($ Total Wattage $*$ Hours of Usage $) 5$} \\
\hline $\begin{array}{l}\text { Energy Cost }=(\text { Wattag } \\
\text { where } \lambda \text { represents } \\
\text { current cost per kWh } \\
(\$ 0.073) \text { using the prev }\end{array}$ & $\begin{array}{l}\text { Hrs of Usage/1000 } \\
\text { kWh rate of electric e } \\
\text { electricity in Nigeria } \\
\text { ng exchange rate of US }\end{array}$ & 6 \\
\hline
\end{tabular}




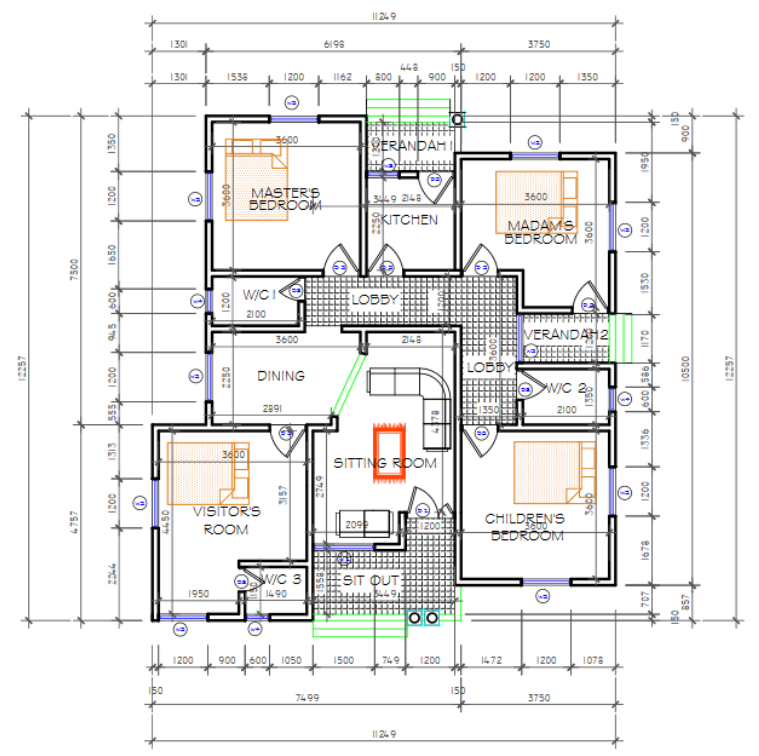

Figure 1. Layout of a typical average residential building in Nigeria

IV. RESULTS AND DISCUSSIONS

The daily $\mathrm{kWh}$ consumption of the two lighting schemes is shown in Figure 2 to 5 , while the daily $\mathrm{kWh}$ consumption of the whole house with the different lighting schemes is presented in Figures 6 to 9.

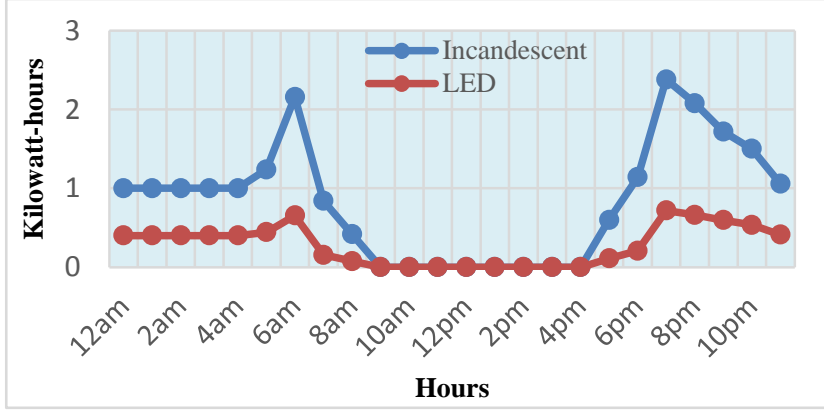

Figure 2. Estimated urban daily kilowatt-hour consumed by incandescent and LED lighting in the building on dry season day.

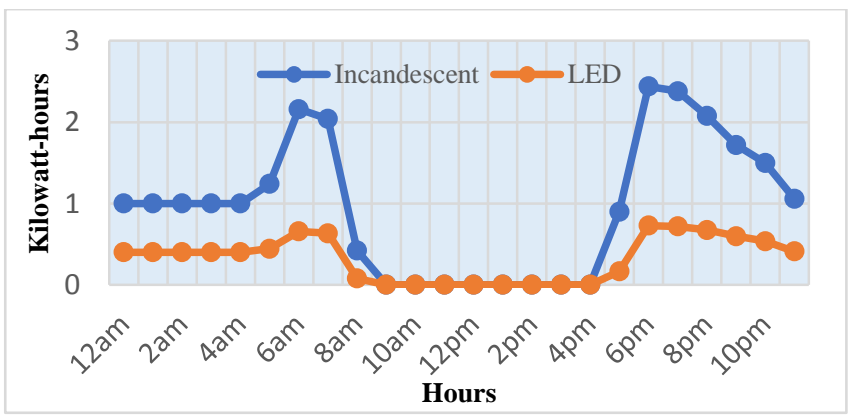

Figure 3. Estimated urban daily kilowatt-hour consumed by incandescent and LED lighting in the building on rainy season day.

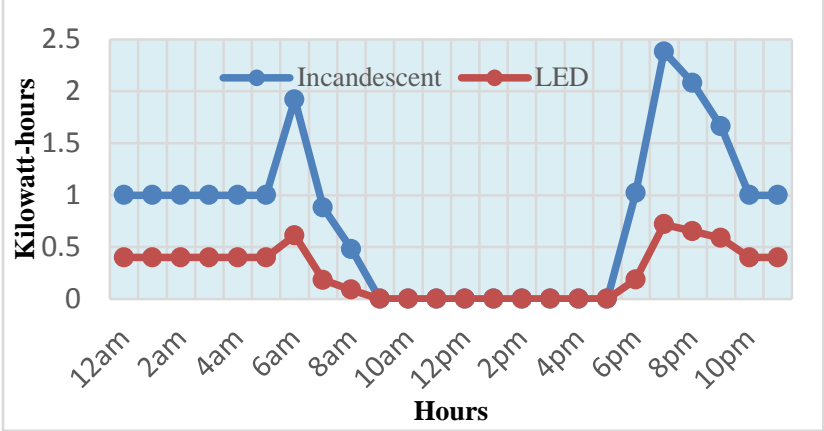

Figure 4. Estimated rural daily kilowatt-hour consumed by incandescent and LED lighting in the building on dry season day.

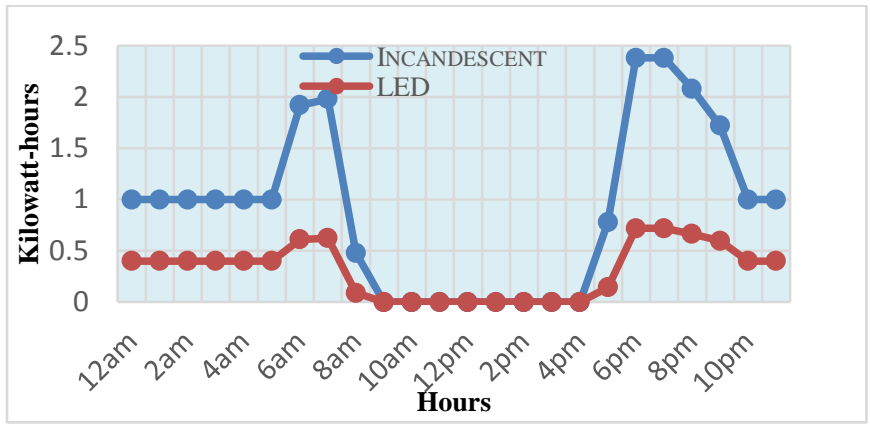

Figure 5. Estimated rural daily kilowatt-hour consumed by incandescent and LED lighting in the building on rainy season day.

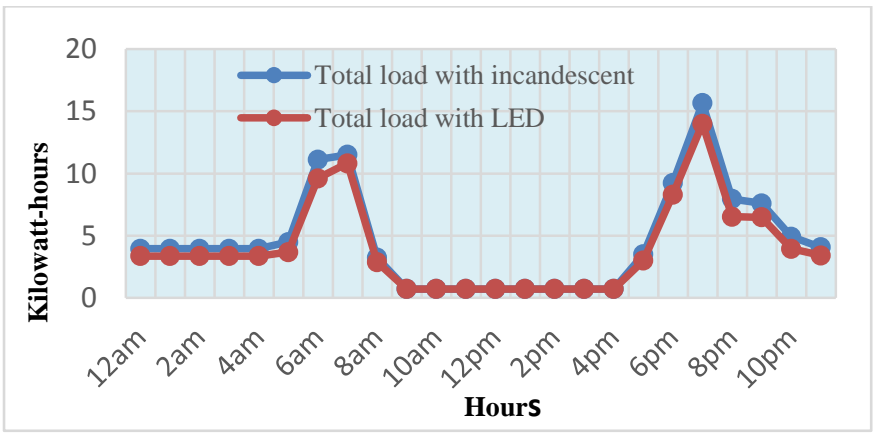

Figure 6. Estimated urban kilowatt-hours consumed by the entire house on a dry season day with both lighting schemes

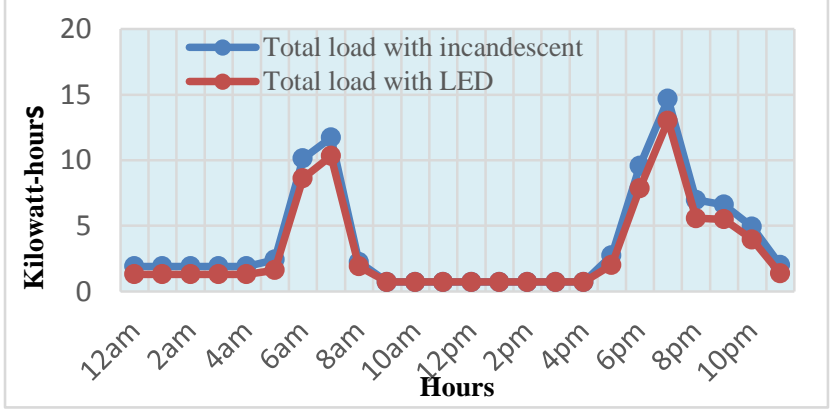

Figure 7. Estimated urban kilowatt-hours consumed by the entire house on a rainy season day with both lighting schemes 


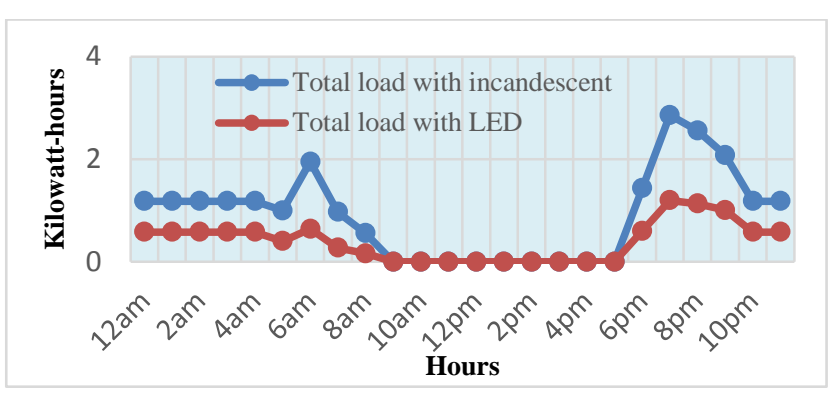

Figure 8. Estimated rural kilowatt-hours consumed by the entire house on a dry season day with both lighting schemes

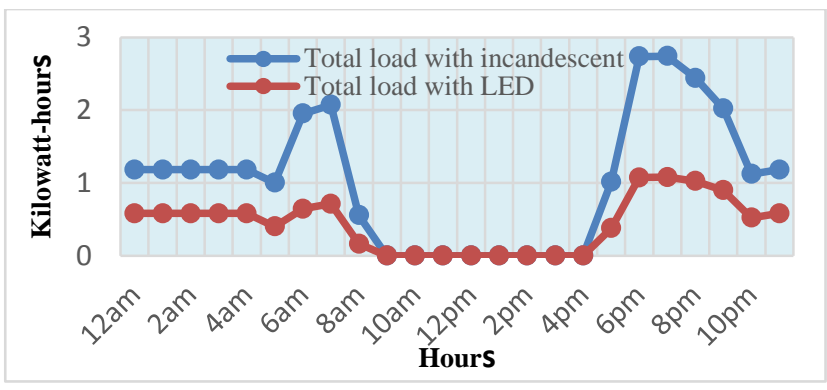

Figure 9. Estimated rural kilowatt-hours consumed by the entire house on a rainy season day with both lighting schemes

The power consumption of each load is estimated based on the rated wattages. The estimated power consumptions are used, along with estimated times of operation to calculate the kilowatt-hours of energy used by each load. The external lighting elements are assumed to be $100 \& 40$ Watts while internal lighting elements are assumed to be 60 \& 11 watts for incandescent and LED bulbs respectively. Only essential loads are considered in this study.

The daily energy consumption of the building is estimated for urban and rural household for both rainy and dry season day respectively. The lighting energy consumption using Incandescent and LED bulbs for both locations is presented in Figures 2 to 5 . The total energy consumption of the building represented in hourly time series for 24 hours for both locations and seasons is shown in Figures 6 to 9. The calculated energy values are then used to find the efficiency of the building electrical loads in terms of lumens provided per watt and watts per square foot of building area. A normal daily energy usage is assumed with constant power supply. The estimated peak load of the building would be used in future research to size a PV plant generation requirements of the model building.

Based on the assumed power consumption by all appliances, utilities and lighting elements of the building the total number of kilowatt-hours used on a Dry season day using incandescent and LED lighting for urban and rural household is $108.90 \mathrm{kWh}, 95.33 \mathrm{kWh}, 21.67 \mathrm{kWh}$ and $9.48 \mathrm{kWh}$ respectively. Similarly, the energy used on a rainy season day using incandescent and LED lighting for urban and rural household is $89.39 \mathrm{kWh}, 74.09 \mathrm{kWh}, 24.73 \mathrm{kWh}$, and
$10.37 \mathrm{kWh}$ respectively. Using these values, the average demand of the building, the load factor, the demand factor, the unit power density and the percentage lighting energy use for a Dry and Rainy season day using incandescent and LED lighting for urban and rural household were computed and presented in Tables 1 to 5 respectively.

TABLE 1: BUILDING AVERAGE DEMAND

\begin{tabular}{|l|l|l|l|l|l|l|l|}
\hline \multicolumn{2}{|l|}{ Urban Dry } & \multicolumn{2}{l|}{ Urban Rainy } & \multicolumn{2}{l|}{ Rural Dry } & \multicolumn{2}{l|}{ Rural Rainy } \\
\hline $\begin{array}{l}\text { Incand. } \\
(\mathrm{kW})\end{array}$ & $\begin{array}{l}\text { LED } \\
(\mathrm{kW})\end{array}$ & $\begin{array}{l}\text { Incand. } \\
(\mathrm{kW})\end{array}$ & $\begin{array}{l}\text { LED } \\
(\mathrm{kW})\end{array}$ & $\begin{array}{l}\text { Incand. } \\
(\mathrm{kW})\end{array}$ & $\begin{array}{l}\text { LED } \\
(\mathrm{kW})\end{array}$ & $\begin{array}{l}\text { Incand. } \\
(\mathrm{kW})\end{array}$ & $\begin{array}{l}\text { LED } \\
(\mathrm{kW})\end{array}$ \\
\hline 4.54 & 3.97 & 3.72 & 3.09 & 0.90 & 0.40 & 1.03 & 0.43 \\
\hline
\end{tabular}

TABLE 2: BUILDING LOAD FACTOR

\begin{tabular}{|l|l|l|l|l|l|l|l|}
\hline \multicolumn{2}{|l|}{ Urban Dry } & \multicolumn{2}{l|}{ Urban Rainy } & \multicolumn{2}{l|}{ Rural Dry } & \multicolumn{2}{l|}{ Rural Rainy } \\
\hline Incand. & LED & Incand. & LED & Incand. & LED & Incand. & LED \\
& & & & & & & \\
\hline 0.29 & 0.28 & 0.25 & 0.24 & 0.32 & 0.33 & 0.38 & 0.48 \\
\hline
\end{tabular}

TABLE 3: BUILDING DEMAND FACTOR

\begin{tabular}{|l|l|l|l|l|l|l|l|}
\hline Urban Dry & \multicolumn{3}{|l|}{ Urban Rainy } & \multicolumn{2}{l|}{ Rural Dry } & \multicolumn{2}{l|}{ Rural Rainy } \\
\hline Incand. & LED & Incand. & LED & Incand. & LED & Incand. & LED \\
& & & & & & & \\
\hline 0.77 & 0.76 & 0.72 & 0.71 & 0.80 & 0.60 & 0.77 & 0.54 \\
\hline
\end{tabular}

TABLE 4: BUILDING UNIT POWER DENSITY

\begin{tabular}{|l|l|l|l|l|l|l|l|}
\hline \multicolumn{2}{|l|}{ Urban Dry } & \multicolumn{2}{l|}{ Urban Rainy } & \multicolumn{2}{l|}{ Rural Dry } & \multicolumn{2}{l|}{ Rural Rainy } \\
\hline $\begin{array}{l}\text { Incand. } \\
\left(\mathrm{W} / \mathrm{ft}^{2}\right)\end{array}$ & $\begin{array}{l}\text { LED } \\
\left(\mathrm{W} / \mathrm{ft}^{2}\right)\end{array}$ & $\begin{array}{l}\text { Incand. } \\
\left(\mathrm{W} / \mathrm{ft}^{2}\right)\end{array}$ & $\begin{array}{l}\text { LED } \\
\left(\mathrm{W} / \mathrm{ft}^{2}\right)\end{array}$ & $\begin{array}{l}\text { Incand. } \\
\left(\mathrm{W} / \mathrm{ft}^{2}\right)\end{array}$ & $\begin{array}{l}\text { LED } \\
\left(\mathrm{W} / \mathrm{ft}^{2}\right)\end{array}$ & $\begin{array}{l}\text { Incand. } \\
\left(\mathrm{W} / \mathrm{ft}^{2}\right)\end{array}$ & $\begin{array}{l}\text { LED } \\
\left(\mathrm{W} / \mathrm{ft}^{2}\right)\end{array}$ \\
\hline 3.47 & 3.04 & 2.85 & 2.36 & 0.82 & 0.36 & 0.93 & 0.39 \\
\hline
\end{tabular}

TABLE 5: BUILDING PERCENTAGE LIGHTING ENERGY USAGE

\begin{tabular}{|l|l|l|l|l|l|l|l|}
\hline \multicolumn{2}{|l|}{ Urban Dry } & \multicolumn{2}{l|}{ Urban Rainy } & \multicolumn{2}{l|}{ Rural Dry } & \multicolumn{2}{l|}{ Rural Rainy } \\
\hline $\begin{array}{l}\text { Incand. } \\
(\%)\end{array}$ & $\begin{array}{l}\text { LED } \\
(\%)\end{array}$ & $\begin{array}{l}\text { Incand. } \\
(\%)\end{array}$ & $\begin{array}{l}\text { LED } \\
(\%)\end{array}$ & $\begin{array}{l}\text { Incand. } \\
(\%)\end{array}$ & $\begin{array}{l}\text { LED } \\
(\%)\end{array}$ & $\begin{array}{l}\text { Incand. } \\
(\%)\end{array}$ & $\begin{array}{l}\text { LED } \\
(\%)\end{array}$ \\
\hline 18.49 & 6.90 & 25.66 & 10.31 & 85.00 & 65.70 & 87.85 & 71.00 \\
\hline
\end{tabular}

Energy consumption, savings and cost resulting from the use of incandescent lamps and LED bulbs are estimated and compared. For the lighting energy cost determination, it is assumed that both the $60 \mathrm{~W}$ incandescent bulbs and 11W LED bulbs are powered using electricity supply from the grid. To determine the energy cost, equation 6 is applied. Only the rainy season day of both locations was chosen for this analysis because of the extended duration of lighting usage. The energy cost is presented in Table 6.

TABLE 6: ENERGY COST RESULTS

\begin{tabular}{|c|c|c|c|}
\hline \multicolumn{2}{|c|}{ Urban Rainy Daily Energy Cost } & \multicolumn{2}{c|}{ Rural Rainy Daily Energy Cost } \\
\hline $\begin{array}{c}\text { Incandescent } \\
\text { Lighting } \\
(\#)\end{array}$ & $\begin{array}{c}\text { LED } \\
\text { Lighting } \\
(\#)\end{array}$ & $\begin{array}{c}\text { Incandescent } \\
\text { Lighting } \\
(\#)\end{array}$ & $\begin{array}{c}\text { LED } \\
\text { Lighting } \\
(\#)\end{array}$ \\
& & & \\
\hline 605.85 & & & 194.43 \\
$(\$ 1.67)$ & 201.77 & 573.63 & $(\$ 0.54)$ \\
\hline
\end{tabular}


To calculate the payback time of any investment, the expenditure over the project duration must be examined. In this case, the life span of incandescent and LED bulbs. For both bulbs, it is assumed that the elements/components would function without defects throughout their respective hour life period which is about 12,000 (4 years) and about 50,000 (17 years) assuming 8 hours of usage per day for incandescent and LED bulbs respectively.

For the $11 \mathrm{~W}$ LED, the payback time is calculated thus: in its 50,000 - hour life an 11W LED will consume $546.04 \mathrm{kWh}$ from equation 5 . Using equation 6 , the energy cost for the LED $=\$ 14,421(\$ 40)$. Adding the unit cost of an LED bulb which is about 400 (\$1.10) will result in a total cost over $50,000$ hours of 14,821 ( $\$ 41)$.

For a $60 \mathrm{~W}$ incandescent bulb, the payback time is calculated using the same procedure. In its 12,000 - hour life, the bulb will consume $700.8 \mathrm{kWh}$ and the energy cost will be $\$ 18,508$ (\$51), for the first 12,000-hour life and $\$ 55,524$ (\$153) for about 50,000-hour life. However, since each incandescent bulb lasts for about 12,000 hours, thus for over 50,000 hours, besides the initial bulb, there may be a need to replace the bulb thrice at a unit cost of 100 (\$0.28), which adds up to $\$ 300$ (\$0.82), thus giving a total of $\$ 58,609$ (\$162) when added to the energy cost and initial bulb cost of $\$ 100$ ( $\$ 0.28)$. Bulb cost is assumed in this study to be constant throughout the 50,000-hour life.

A comparison of the overall unit cost of bulb and energy for the incandescent and LED lighting systems determined above over a 50,000 hours period will result in a unit gain of $\$ 43,788$ (\$121) if an LED bulb was used. This is the cash saving per unit of bulb besides other considerations. Multiplying this value by the total number of bulbs (41) in the model layout will result in a total cash savings of $\$ 1,795,308$ $(\$ 4,959)$.

With the previous assumptions regarding the hour life of both the incandescent and LED bulbs, a simple return on investment is determined. Using the initial unit cost for an $11 \mathrm{~W}$ LED bulb of $\$ 400$ ( $\$ 1.10$ ), with energy consumption of $109.2 \mathrm{kWh}$ in every 10,000 hours of use would amounts to an electricity cost of $\$ 2,884$ (\$8) using equation 5. This sequence will continue, thus giving the cost after 10,000 hours of use to be $\$ 400+\$ 2,884=\$ 3,284$ (\$9).

For incandescent bulb, the initial cost of a $60 \mathrm{~W}$ bulb is $\$ 100$ (\$0.28) and has about 12,000 hour life. Just like the former, in each 12,000 hours, the electricity consumption will be $700.8 \mathrm{kWh}$, which costs $\$ 18,508$ (\$51). In a similar pattern, the initial cost is taken to be the cost of the bulb which is $\$ 100$ ( $\$ 0.28)$. At the end of the first 12,000 hours, a new bulb is replaced and the energy cost is added $\$ 18,508+$ $\$ 100+\$ 100=\$ 18,708$ (\$52). Thus after another 12,000 hours, another energy and bulb cost will be added which adds up to $\$ 37,316$ (\$103). This continues over the 50,000 hour life period.

\section{CONCLUSION}

The role of energy efficiency and savings in the achievement of the sustainable development goals cannot be overemphasized. Residential energy use plays a key role in the global energy-related environmental problems. From the analysis, it is clear that the percentage of energy used for lighting was significantly high especially in the rural household model and the use of LED bulbs for lighting greatly reduced both the energy cost and improve energy efficiency. Resulting from the analysis of both lighting schemes, the simple return on investment indicates that using LED bulbs although having an initial higher acquisition cost, can quickly break even due to its lower energy consumption and long hour life. It is believed that the results of this study would influence the decisions of energy users and policy maker especially in developing countries as the study concludes that incandescent lights are inefficient lighting devices, and are responsible for more residential energy consumption than is required for their desired output. The sizing of a PV system using this model and further optimization of different residential housing models using Smart Residential Load Simulator would be the focus of the next research.

\section{ACKNOWLEDGMENT}

The authors gratefully acknowledge TETFund Nigeria for the sponsorship. We also appreciate the contributions of Inimfon-Abasi Okure for helping with the data collection.

\section{REFERENCES}

[1] IEA. 30 Years Of energy use in IEA countries. Paris: International Energy Agency; 2004. Retrieved March 29, 2019, from International Energy Agency: https://www.iea.org/weo2017/

[2] IEA. Energy balances. Paris: International Energy Agency; 2007. Retrieved March 29, 2019, from International Energy Agency: https://www.iea.org/statistics/balances/

[3] A. Keyhani, Design of smart power grid renewable energy systems $2^{\text {nd }}$ ed. New Jersey: Wiley \& Sons, Inc. 2017. pp. 193.

[4] The international Energy Agency (IEA) energy efficiency 2018 report. Retrieved March 29, 2019, from International Energy Agency: https://webstore.iea.org/market-report-series-energyefficiency-2018

[5] Y. Udoakah and I. Okure Enery, "Energy efficiency and sustainability: Evaluation of electricity consumer's behavior towards electricity usage and energy conservation," International Journal of Science and Technology, 6(2), pp. 36-52, 2017.

[6] O. Adeoti, B. A. Oyewole, and T. D. Adegboyega, "Solar photovoltaic-based home electrification system for rural development in Nigeria: domestic load assessment," Renewable Energy, 24, pp. 155-161, 2001.

[7] S. O. Oyedepo, "Efficient energy utilization as a tool for sustainable development in Nigeria," International Journal of Energy and Environmental Engineering, 3:11, pp. 1-12, 2012.

[8] Y. Irimiya, I. A. Humphery and I. I. Aondover, "Assessment of energy use pattern in residential buildings of Kano and Kaduna Northern Nigeria," American Journal of Engineering Research, 2:10, pp. 271-275, 2013.

[9] T. R. Ayodele and A. S. O. Ogunjuyigbe, "Increasing household solar energy penetration through load partitioning based on quality of life: The case study of Nigeria," Sustainable Cities and Society, 18, pp. 21-31, 2015.

[10] W. Kersting, Distribution system modeling and analysis $2^{\text {nd }}$ ed. New York: CRC Press, Taylor \& Francis Group, 2007. pp. 13-21. 